\title{
THE PERFORMATIVITY OF DIGITAL STORIES IN CONTEXTS OF SYSTEMIC INEQUALITY
}

\section{Gachago}

Educational Technology Unit

Cape Peninsula University of Technology

Cape Town, South Africa

e-mail: gachagod@cput.ac.za

\section{ABSTRACT}

Digital storytelling has entered Higher Education over recent years as a tool to engage diverse classrooms, harnessing the power of personal storytelling to establish affective connections across difference. This article reports on a digital storytelling project in the context of South African teacher education, where students reflected on a social issue in Education, as a means to understand systemic inequalities governing our classrooms. Moving beyond Butler's notion of performativity, towards an understanding of how both human and non-human matter can shape subjectivities as suggested by new materialist feminist authors such as Barad this study will explore how one student, her story and the audience are entangled in and across space and time. I will show how digital storytellers are both composer and composed: how within the digital story process, stories create the possibility for storytellers to experiment with new subjectivities that could become real with time and repeated performance but how these stories also act upon the storyteller based on the context the story is told in. I will also reflect on how our entanglements foreground the importance of an ethical and responsible engagement with the power of stories in the context of socially just pedagogies.

Key words: digital stories, performativity of matter, companion species, new materialism

One is undone, in the face of the other, by the touch, by the scent, by the feel, by the prospect of the touch, by the memory of the feel. We are touched by stories we tell. (Judith Butler 2004).

\section{INTRODUCTION}

Storytelling has been long used as a pedagogical tool that allows diverse learners in the classroom to unearth lived experiences and to facilitate a more nuanced understanding of difference (Aveling 2001). The increased use of digital technologies has made it possible for personal storytelling to extend its reach beyond the act of telling a story, through recordings and online sharing. Digital storytelling - a method and a genre - leverages the power of digital media to give voice to stories that are usually not heard in mainstream media (Lambert 2013). A digital story as defined in my study is a personal narrative that documents a wide range of culturally and historically embedded lived experiences combining voice, sound and images into 
a short video, developed by non-professionals with non-professional tools within the context of a digital storytelling workshop (Lambert 2013; Reed and Hill 2012).

At the core of the digital storytelling process is the belief that telling stories can make a difference in people's lives and in how people engage with each other across difference. Storytelling can lead to wisdom, compassion and conscience, as Reed and Hill (2012, n.p.) explain:

... personal stories can inspire, educate, and move people deeply, and [...] when it comes to confronting complex social issues, the connections forged through storytelling can help people bridge the vast differences that often divide them and instead act with wisdom, compassion, and conscience.

Proponents of digital storytelling foreground the centrality of emotions shared and expressed in the process of developing a digital story, such as the establishment of an affective connection with the audience. As Burgess (2006, 210) reminds us:

For the storyteller, the digital story is a means of 'becoming real' to others, on the basis of shared experience and affective resonances. Many of the stories are, quite literally, touching.

This is of particular interest when using digital storytelling as a socially just pedagogy (Moje 2007) in post-conflict societies, such as South Africa, as it would mean that the mere act of telling and listening to digital stories could allow students to empathise with one another, challenge some of their cherished beliefs and assumptions, and develop a more critical awareness of how systemic and structural injustices impact on engagement across difference in the classroom.

How does this happen? Is it the story that elicits empathy? Or the storyteller? Or the entanglement of story and storyteller? What is the role of the audience in this process? This article focuses on this entanglement, what digital stories do - seeing stories as actors, having agency, as shaping, co-constituting rather than reflecting human subjectivities (Frank 2010; Juelskjaer 2013).

This article draws from a study within a pre-service teacher education programme, in which students were encouraged to create counterstories (Solorzano and Yosso 2002) on issues of social justice that moved them. The aim of this project was to promote a growing understanding of the systemic inequalities that govern our classrooms through the sharing of these stories (Gachago et al. 2013; Gachago 2015b; Gachago et al. 2014).

In previous research I have used Butler's notion of performativity of gender, race, class and sexuality to show if and how some stories are better suited, have different capabilities in relation to elicit audience empathy (Gachago 2015a). However, where I stumbled when using 
Butler's notion of performativity, is in the attempt to understand how storyteller, story and audience are entangled.

Can performativity simply be transferred onto digital stories, which, contrary to real-life performance, are mediated, representational and constructed narratives? In queer feminist theory, performativity is a human affair, as Barad (2011) notes. Can performativity be applied to a nonhuman object, such as a digital story? Can the repeated performance of a digital story act upon the storyteller's subjectivity? Can the repeated sharing of digital stories trouble the way a storyteller does gender, race, class and sexuality? And what happens to the audience who listens to these stories?

This article will explore how one storyteller's subjectivity and body was shaped by the process of story creation, writing, crafting and repeatedly performing as a digital story both in her absence and in her presence by looking at the entanglement of human and non-human matter over space and time.

\section{HUMAN AND NON-HUMAN PERFORMATIVITY}

This study draws firstly on the humanistic approach of queer theorist Butler's (2004; 1999) conceptualisation of gender as performative, discursive and relational. Butler defines queer as a 'site of collective contestation' to be 'always and only redeployed, twisted, queered' (1993, 223), a space first and foremost for contesting gender and sexuality, but eventually anything that is normal, legitimate and normative, such as race or class. In her work, she aims to unsettle stabilising, dichotomous gender categories (man/woman) which attempt to normalise and regulate people, by demonstrating how gender is discursively produced through repeated performance and how this repeated performativity constitutes a subject (Jackson and Mazzei 2012). One of her most famous theoretical concepts is that gender becomes a verb (as opposed to being a noun), constituting something somebody does repeatedly. This performative doing constitutes, rather than merely expresses, identity:

... gender proves to be performative - that is, constituting the identity it is purported to be. In this sense, gender is always a doing, though not a doing by a subject who might be said to preexist the deed. (Butler 1999, 32, my emphasis).

Butler continues to explain: '... if gender is performative, then it follows that the reality of gender is itself produced as an effect of the performance' (2004, 218, my emphasis). What is important here, as she notes, is the repeated nature of discursive gender construction (1999, 4344, my emphasis): 
Gender is the repeated stylization of the body, a set of repeated acts within a highly rigid regulatory frame that congeal over time to produce the appearance of substance, of a natural sort of being.

This distinction between expression and performativity of gender is crucial, for as Butler explains: if gender is performed rather than expressed, no pre-existing gender identity can then be assumed by which this act can be measured. Hence, she concludes, there might not be any 'true or false, real or distorted acts of gender, and the postulation of a true gender identity would be revealed as a regulatory fiction' (Butler 1999, 180).

This quote delineates the two major functions of gender performativity, the first being that gender establishes us as humans. Secondly, we not only perform or are assigned gender through our acts, but also perform or are assigned gender through our speech acts. As Bury $(2005,8)$ points out:

Butler's claim that gender is an effect rather than the cause of 'words, actions and gestures' suggests that gender performance is not just about ways of walking but ways of talking. It is not only what I do that makes me recognizable as a woman but what I say and how I say it.

Furthermore, while gender is always 'done', Butler's humanistic perspective asserts that it is not done by a subject on his or her own, but always in relation to somebody else, even if this somebody is imagined. It follows that if terms such as masculinity and femininity are discursively constructed, they are also historically contextualised and as such continually reconstituted to change meaning (Butler 2004).

This notion of a discursive performance of gender is interesting in the context of digital storytelling, and in particular when analysing the digital stories that are the outcome of such a process. Can Butler's notion of performativity of gender, race, class and sexuality be transferred on digital stories, which, contrary to real-life performance, are mediated, representational narratives, co-constructed with an audience? Can performativity be applied to a non-human object, such as a digital story? Can a non-human object, such a digital story, constitute a human? Can the repeated performance of a digital story co-constitute and shape the storyteller's subjectivity? Can we do gender, race or sexuality differently in our stories? And what happens to the audience in this process?

Barad takes Butler's concept of performativity further by challenging the emphasis on the human body as the only body that matters, that is attached to life, excluding 'bodies that get placed on the other side of life, of liveliness, those that aren't worthy of death, those that don't measure up when it comes to death?' $(2012,20)$. She argues that 'all bodies, not merely human bodies, come to matter through the world's performativity - its iterative intra-activity'. (Barad 
2011, 125)

While a discussion of the complexities of the way Barad disrupts traditional notions of identity and difference deserves more space than I can give here, I want to draw attention to a few important notions in Barad's onto-epistemology and how it impacts on the performativity of digital stories. First what is important to understand, is that in Barad's (2007) world subject and object are not separated, but that they are closely entangled. In stark contrast to Butler, Barad is not interested as such in how bodies are positioned in the world, but how bodies are constituted along with the world, along with matter, as 'part' of the world (Barad 2007, 170). Furthermore Barad disrupts binary notions such as that of gender by drawing from metaphysical examples that question the linearity of space and time. Barad's (2007) concept of 'intra-action’ establishes entities not as pre-existing the relationships that enact them, but rather as emerging through their intra-action. Intra-actions of the apparatus - the machine or lens producing data/matter - and the researcher, produce phenomena that are not always logical or explainable within traditional science. They are relational, and are enacted through, what Barad calls, agential cuts, 'cutting together-apart' (Barad 2012, 20), differentiating and entangling at the same time, in one move (Barad 2011). What follows, is that individual entities are not separate, but bounded and entangled phenomena that extend across space and time: 'Phenomena are entanglements of spacetimematter, not in the colloquial sense of a connection or intertwining of individual entities, but rather in the technical sense of "quantum entanglements", which are the (ontological) inseparability of agentially intra-acting “components”” (Barad 2011, 125). As difficult as this is to understand, she shows through physical experiments, that in this entanglement of apparatus and matter, an ontology is subject to change and dependent on the apparatus used. As she explains: 'Thus, we have empirical evidence of the fact that the atom's identity, its ontology, is never fixed, but is always open to future and past reworkings!'. As such space and time are intra-actively produced within the phenomena - 'neither space nor time exists as a determinate given outside of phenomena' (Barad 2011, 145). This dis/continuity helps us to avoid the dichotomies of past/present and stasis/change (Juelskjaer 2013).

What does this mean for this study, and what does it mean for the study of phenomena in general, the entanglement of storyteller, story and audience - an audience that includes me as the researcher as part of the apparatus (Barad 2007, Juelskjaer 2013)?

A useful approach to thinking about performativity of stories draws on Haraway’s work on 'companion species' (2008), seeing stories as what she terms 'material semiotic companions', in the sense that good companions take care of each other. This involves shaping the other, enabling the other to be in the entanglement of subject and matter. Stories are 
performative, in the sense that as Law (2000) explains, they 'also make a difference, or hope to make a difference' (cited in Frank 2010, 42). They are 'made of air but leave their mark' (ibid, 43). Digital stories make this companionship visible, as they can be told both with the storyteller physically present or absent as when the story continues through the voices, images and the narrative of the digital. Stories are there and not there - alive in the audience imagination, with or without the storyteller's knowledge. Digital stories blur the boundaries between private and public, reality and fiction (Jimroglou 1999).

\section{RESEARCH APPARATUS}

According to Barad, the research apparatus determines the phenomena and as such needs to be included in the research design (Barad 2007; Juelskjaer 2013). Depending on the apparatus the outcome of an experiment may differ, the identity of the matter shaped: 'As specific materialdiscursive practices, apparatuses enact agential cuts; cuts that constitute boundaries, categories and "properties" of phenomena, cuts through which specific concepts and specific materialdiscursive reconfigurations of the world become meaningful' (Juelskjaer 2013, 757).

This study is set within the Faculty of Education and Social Sciences at a large university of technology in the Western Cape. This project was introduced in order to reveal students' understandings of their diverse backgrounds, their own and their peers' social positioning visà-vis personal, institutional and systemic structures. It was set up in response to Department of Education policy to prepare future teachers for diverse classrooms (Department of Education 2001; Desai et al. 2004). It was hoped that the nature of a digital storytelling project focusing on new media technology and innovative practices would motivate and empower students to engage with difficult topics, such as race, class, gender and sexuality, uncomfortable issues that are frequently resisted in today's South Africa. Furthermore we aimed to increase their awareness of the systemic inequalities that govern our classrooms (Gachago et al. 2014; Gachago et al. 2013).

The final year pre-service teacher education student who I will focus on in this article, volunteered as peer facilitator in the 2013 project. In posthuman research we look for data that 'glows' (Maclure 2013, 661). Each year, there are specific stories that stand out and that students refer to more often than to others. The story developed by Lauren was the one that glowed for me. Certain stories impact us through their authenticity and personal connection, eliciting more emotional engagement than others. The story from Lauren was about a usually silenced topic in SA classrooms: her sexuality. This story had a particular force that troubled the hetero-patriarchal norms that govern usual engagements in the classroom. From the onset 
this story attracted particular interest in the project in its objective to facilitate an engagement across difference. It stayed with me, haunting me for a long time, leaving its mark on me that led to this story becoming part of my $\mathrm{PhD}$ studies along with another one dealing with issues of race. Because of its provocative content, in tandem with its aesthetic form and Lauren's creativity, the story often offers itself to be shown in workshops or conferences. This story and I have been entangled together for many years now, shaping my thinking about digital storytelling and student narratives.

Following Juelskjaer's lead (2013), I have revisited the interviews I conducted with Lauren and observations I wrote down during my work with her and her peers, and looked at them through a different lens: one that would allow me to explore the entanglement of human and non-human matter, the entanglement of story, storyteller, audience and researcher, across time and space. The narratives emerging from her story and in the interview are not objective truths, representations of reality, but co-constructed, situated, contextualised performances, in/with time and space a strong constituent of this 'material articulation of the world' (Barad 2007, 139). Lauren's story was mobilised in the context of a social justice project, with a particular encouragement to produce a counterstory (Solorzano and Yosso 2002), i.e. one that would challenge dominant discourses in the class. Lauren's story is a 'coming out' story, reflecting elements of this genre, such as isolation and lack of support from family and school, a growing sense of discomfort of living a lie, and the decision to finally live her own life on her own terms. Homosexuality is a silenced topic within South Africa's classrooms. Despite having a most progressive constitution, within conservative South African society homosexuality is not widely accepted (Graziano 2005; Visser 2007). This story appeared to give her the courage to come out to her class as an act of bravery despite a high risk of potential victimisation. This story was and still is repeatedly performed outside the classroom space to wider audiences where Lauren was both present and absent. In the following section I will look at five of these events, five phenomena, applying five agential cuts, that show the entanglement of story, storyteller and audience. These scenes, although linear in time show how the present, the past and the future can co-constitute each other in interesting ways, disrupting the notion of temporal and spatial linearity thereby by engaging with different 'versions' of Lauren's subjectivities.

Ethical clearance was sought through institutional channels and Lauren gave informed consent to be part of this study.

\section{A STORY AND ITS ENTANGLEMENTS}




\section{Scene 1}

Lauren performed her digital story for the first time in the relative safe space of a five-day digital storytelling workshop for peer facilitators. Lauren had shared her story in the various steps of becoming to her peers. The final product, however, was shown first in a final screening on day 5 of the workshop. Although the usual audience for this screening consists of the participants in this workshop, I had invited a few of my colleagues to the screening - to prepare students for the potential discomfort they might feel when sharing their stories at a later stage with their classmates, as was expected of them. Showing her story to her peers was nervewrecking for Lauren, sharing it in front of strangers terrifying. In an interview I did with her shortly after the end of the project, she reflects on how she suddenly felt highly vulnerable:

Lauren: I thought that in the room there were people ... I have no idea who they are ... it could be in their culture and their belief that they ... maybe they've even done it to someone [referring to corrective rape] and that actually scared me because I don't wanna ... if I were to walk out of this building and someone were to ...

Daniela: .... accost you?

Lauren: Yeah ... that's the scary thing about revealing the story .... (Interview 1 with Lauren)

\section{Scene 2}

The story was then showed to her classmates. This is an extract of my research journal:

The room is packed. We are reaching the end of the lesson, which as usual took much longer than planned. I wonder whether I should show Lauren's movie as planned or wait till the next week. Siyabonga stands up and reminds me that we had planned to show Lauren's movie. I look at Lauren. She looks pale and nervous. I hesitate, suddenly worrying about her but she nods, and I start the movie. During the screening of her movie there is complete silence in the class. I look around and see people's gaze fixed on the screen. Lauren sits in the front row with her back to the audience. When the movie ends, the silence continues. Holding my breath, I wait to see her class's reaction. Suddenly one of the women stands up and starts clapping. Others follow and finally the class is all standing, giving Lauren a standing ovation. People are hugging and crying; the room vibrates with emotion. It is the end of the class, so students leave, but many first approach Lauren to hug her and congratulate her on her courage in breaking the silence around this topic. Lauren beams and looks very happy.

\section{Scene 3}

Lauren's story was contagious; it moved and helped others in the process to tell their own stories. She offered others her story and invited them to inhabit and appropriate this story for themselves, with material consequences. Siyabonga for example, though careful not to reveal his sexuality to his class, related in an interview how Lauren's story encouraged him come out to his family.

Siyabonga: I was telling her [Lauren] about the story, her story ... and then she said to me: You know what? The day I was telling my story you cried and then I noticed ... and then 
she said: I knew those tears were not for nothing! I said: Hell no, you saw me very well (laughing) ... yeah because I was living a lie and then I thought, if Lauren can be so, so brave about her sexuality, revealing about her sexuality in class and with her family, why I can't I do it? (Interview 1 with Siyabonga)

\section{Scene 4}

As a political act for increasing lesbian, gay, bi, trans and intersex (LGBTI) visibility and destigmatizing identities, literally overnight, Lauren became a LGBTI activist, expert on all matters concerning LGBTI and a support person for peers struggling with similar issues. A number of students emailed her asking her for help and advice on how to come out to their own families.

This story not only shifted the way Lauren's peers perceived her, but also influenced how Lauren's sense of self shifted, as she reflected in an interview shortly after the end of the project:

Lauren: This whole thing has like changed my whole, like I don't wanna teach next year. I was set on, like I am gonna teach next year. And now I wanna like focus on a forum for homosexual youth and like a place where people can come, where it's safe to talk and just to talk about issues. Like especially focusing on being black and gay. In that culture and I wanna write a paper on it as well. So like it's completely changed my part. Like I have applied for my Honours I will do that ... (Interview 1 with Lauren)

\section{Scene 5}

Approximately one year later after the original project I interviewed Lauren again. Her story and I had developed an intense relationship during this period as I analysed it through a finegrained multimodal methodology, focusing for a long time on each and every image. As a researcher this story linked me to Lauren through an intimate connection with a version of Lauren frozen in time. Lauren in this year had moved on, she had started to work as a teacher and continued her work as LGBTI activist, becoming more and more vocal about issues of difference both in her teaching and private life. When I asked her about what she thought about her story now, I was in for a surprise.

Lauren: When I watch my story now, I feel I hate it. Like I just hate how it's done. There is so much that I would want to change ... there wasn't the time, at the time when we made it. Just the way that it flows, it feels very immature, when I watch it now .... Since then, I have grown so much, because I have been more out ... I don't know how to explain it. But I feel like now I, I could speak with more powerful words, the pictures I use would probably be so different.

It would probably be the same, like I would come from a personal angle, but the way that I would approach it within society, I would approach it differently, I would not try and come across, like, I would not try to win people over, be more, like, not factual, but if you want to hate gay people, then hate them .... My old story makes me feel like I was trying to convince people that they should actually understand what it means to be homosexual, this is actually not what my aim was .... It was more to say that we are people, that was my aim, but I don’t feel that my story conveyed that, I felt like I was 
trying so hard to persuade people to like me for who I am ... when actually they don't have to, you know ... I would do it quite differently, yeah .... (Interview 2 with Lauren)

\section{HOW THE STORIES WE TELL INFLUENCE OUR BEING AND BECOMING}

The scenes narrated above, although chronologically ordered, show the iterative intra-actions and entanglements of story, storyteller and audience in and across space and time. Digital stories are complex multi-layered orchestrations of different multimodal texts: language, images, sound and storytellers' voices affectively and effectively connect their bodies to their digital stories. This orchestration is not an easy task: how the various modes work or do not work together can counter authorial intent and can have a strong - sometimes unintended - impact on audience response (Gachago 2015a).

By creating a digital story, storytellers have the possibility of experimenting with different variations of self that could become real with time and repeated performance. However, while her digital story is a mediated, constructed, representational narrative told by Lauren for a specific reason, i.e. to break the silence around homosexuality in her classroom, it also acts upon Lauren. As Nelson, Hull and Roche-Smith (2008) argue, representations of self in written, but even more so in multimodal texts is can take on a life of their own, are out of control (Frank 2010). Digital matter has a force that then becomes performative: Lauren's story terrified her, made her vulnerable, but also proud, positioned her as social activist, LGBTI expert and role model and finally embarrassed her depending on time, space and audience. Here the entanglement of human and non-human matter, of subject and object, the companionship of story and storyteller becomes visible: the self and the body are both enacted and acted upon in the process of writing, crafting and repeatedly performing digital stories, as digital storytellers are both composer and composed (Jimroglou 1999).

Furthermore, the digital format allowed Lauren’s story to travel beyond the workshop and the classroom as it was and continues to be shown in other classrooms, workshops, conferences and shared online. The specific affordances of a digital story, the possibilities of recording and sharing a story that represents a moment in time, allow a continuous co-constitution of story, storyteller and audience based on the context, time and audience the story is told to - both real and imagined, with an absent yet present storyteller. Lauren's story not only acted on herself, but affectively and effectively touched and continues to touch many different audiences. Her story made and continues to make others share their stories: peers came out to her, to their families, in their iterative intra-actions with her story constituting and re-constituting themselves and others.

Interesting phenomena emerged in the process of researching Lauren's story that 
challenged my traditional understandings of time and space, allowing me to make sense of Barad's complex notion of 'timespacemattering'. As I continued to multimodally analyse Lauren's digital story in detail over many, many months, getting deeper and deeper entangled in that specific time-bound performance, she had continued with her life, her thoughts about her story and herself transformed, seemingly leaving the persona performed in the story behind. However, as Barad (2007) notes, we can never leave our past behind. We are always and already our past, present and future. Lauren's story created many versions of Lauren, which continue to live simultaneously side by side, as reflected by how this story is perceived by her audience, including myself. As I was talking about my reading of a previous version of Lauren with Lauren in one of our last conversations together, the more recent Lauren both constituted how I read and understood the Lauren of the past. At the same time reflecting on past versions of Lauren and my reading of her story, re-constituted the Lauren I was in conversation with at the moment. Lauren's plans for her future impacted how I saw her current and past self. As such various iterations of Lauren's past, present and future subjectivities lived and are still living in parallel, bounded and entangled phenomena extending across space and time, constituting each other (Barad 2011). Using Juelskjaer's (2013, 761) words, Lauren in her final interview 'was now of another landscape that was continuously shaped by and shaping her'.

When does a digital story become obsolete? What happens to Lauren in the story when Lauren beyond the story moves on? What happens or should happen when Lauren cannot or doesn't want to identify with the Lauren in the story anymore? This project sharpened my sense of responsibility towards Lauren and her story, as Barad (2012, 20) notes: 'In performing the labor of tracing the entanglements, of making connections visible, you're making our obligations and debts visible, as part of what it might mean to reconfigure relations of spacetimemattering'. Only when we consider all the different Lauren's that were produced in the performance of these stories, can we start to grasp the 'thickness' of subjectivities, as Juelskaer reminds us (2013). Lauren is not just a young woman in my study writing a story about coming to terms with her sexuality within a conservative family context in order to fulfil her assignment brief. In the scenes above she emerges as a social activist, breaking silences in her classroom, as a supportive friend, advising on how best to engage family with being different, as a research partner, forever entangled in my PHD journey, and finally a critical educator, concerned with developing critical thinkers.

In my iterative intra-actions with her and her story my indebtedness to her led to a growing sense of her and my own vulnerability - a vulnerability bound in an entangled responsibility towards not only Lauren and her story, but towards all the students who have shared and 
continue to share their stories with me. These stories are fragile, yet powerful. This responsibility becomes particularly pertinent in the context of socially just pedagogies, where we encourage students to tell stories of a specific kind, aimed at countering dominant narratives: are we always aware of the ethical considerations when encouraging our students to break the silence on difficult topics? Here Barad's (2007, x) notion of living justly and responsibly in the world (also called upon by other authors in this special issue, see Bozalek et al.), is useful as it reminds us, that justice is not a state that can be achieved, but rather a practice, an on-going practicing of our ability to be open, to respond to every intra-action with human and non-human matter.

Stories develop and are not held or told in a vacuum. They do not disappear once they are told. In the digital space they become matter that matters, performed and performing, disrupting traditional ways of what matters. They shape and are shaped by the person telling the story, but also their audience and the space they are told into. They have material consequences, emotional and physical, they are powerful and often 'out of control' (Frank 2010). They are companions, not always loved ones but ones that shape us and continue to mark us long after we have left the multiple space-times into which the story was performed. As Juelskjaer $(2013,756)$ writes, there cannot be knowing from a distance - we are indebted to the other through our entanglement with the other.

\section{REFERENCES}

Aveling, Nado. 2001. 'Where do you come from?': Critical storytelling as a teaching strategy within the context of teacher education. Discourse: Studies in the Cultural Politics of Education 22(1): 3548.

Barad, Karen. 2007. Meeting the universe halfway. Durham and London: Duke University Press.

Barad, Karen. 2011. Nature’s queer performativity. Qui Parle 19(2): 121-158.

Barad, Karen. 2012. Intra-active entanglements. Kvinder, Køn og Forskning/Women, Gender and Research 1-2(1):10-23.

Burgess, Jean. 2006. Hearing ordinary voices: Cultural studies, vernacular creativity and digital storytelling. Continuum: Journal of Media \& Cultural Studies 20(2): 201-214.

Bury, Rhiannon. 2005. Cyberspaces of their own: Female fandoms online. New York: Peter Lang Publishing.

Butler, Judith. 1993. Bodies that matter: On the discursive limits of 'sex'. New York: Routledge.

Butler, Judith. 1999. Gender trouble: Feminism and the subversion of identity. New York and London: Routledge.

Butler, Judith. 2004. Undoing gender. New York and London: Routledge.

Department of Education. 2001. National plan for Higher Education. Pretoria: Department of Education. http://sun025.sun.ac.za/portal/page/portal/Administrative_Divisions/INB/Home/ Documentation/Documentation_National/National Plan for Higher Education in South Africa.pdf

Desai, Zubeida et al. 2004. Manifesto on values, education and democracy. Pretoria: Department of Education. http://www.info.gov.za/view/DownloadFileAction?id=70295 
Dolphijn, Rick and Iris van der Tuin. 2012. New materialism: Interviews and cartographies. Open Humanities Press. http://openhumanitiespress.org/new-materialism.html

Frank, Arthur W. 2010. Letting stories breath: A socio-narratology. Chicago and London: The University of Chicago Press.

Gachago, Daniela. 2015a. Sentimentality and digital storytelling: Towards a post-conflict pedagogy within the context of South African pre-service teacher education. Unpublished doctoral thesis, School of Education, University of Cape Town.

Gachago, Daniela. 2015b. Owning your emotions or sentimental navel-gazing: Digital storytelling with South African pre-service student educators. In Telling stories differently: Engaging 21st century students through digital storytelling, ed. J. Condy. Stellenbosch: SUN Press.

Gachago, Daniela, Franic Cronje, Eunice Ivala, Janet Condy and Agnes Chigona. 2014. Using digital counterstories as multimodal pedagogy among South African pre-service student educators to produce stories of resistance. Electronic Journal of e-Learning (eJeL) 12(1): 29-42.

Gachago, Daniela, Eunice Ivala, Janet Condy and Agnes Chigona. 2013. Journeys across difference: Pre-service teacher education students' perceptions of a pedagogy of discomfort in a digital storytelling project in South Africa. Critical Studies in Teaching and Learning 1(1): 22-52. http://cristal.epubs.ac.za/index.php/cristal/article/view/4/6

Graziano, Kevin J. 2004. Oppression and resiliency in a post-apartheid South Africa: Unheard voices of black gay men and lesbians. Cultural Diversity and Ethnic Minority Psychology 10(3): 302-316.

Haraway, Donna. 2008. When species meet. Minneapolis and London: University of Minnesota Press.

Jackson, Alecia Y. and Lisa A. Mazzei. 2012. Thinking with theory in qualitative research. New York: Routledge.

Jimroglou, Krissi M. 1999. A camera with a view. Information, Communication \& Society 2(4): 439453.

Juelskjaer, Malou. 2013. Gendered subjectivities of spacetimematter. Gender and Education 25: 754768. http://www.tandfonline.com/doi/abs/10.1080/09540253.2013.831812

Lambert, Joe. 2013. Digital storytelling: Capturing lives, creating communities. 4th ed. New York: Routledge.

Maclure, Maggie. 2013. Researching without representation? Language and materiality in postqualitative methodology. International Journal of Qualitative Studies in Education: 37-41.

Moje, Elizabeth B. 2007. Chapter 1: Developing socially just subject-matter instruction: A review of the literature on disciplinary literacy teaching. Review of Research in Education 31(1): 1-44.

Nelson, Mark E., Glynda A. Hull and Jeeva Roche-Smith. 2008. Challenges of multimedia selfpresentation: Taking, and mistaking, the show on the road. Written Communication 25(4): 415440. http://wcx.sagepub.com/cgi/doi/10.1177/0741088308322552

Reed, Amber and Amy Hill. 2012. 'Don’t keep it to yourself!': Digital storytelling with South African youth. International Journal for Media, Technology and Lifelong Learning 8(2). http://seminar.net/index.php/component/content/article/75-current-issue/146-dont-keep-it-toyourself-digital-storytelling-with-south-african-youth

Solorzano, Daniel G. and Tara J. Yosso. 2002. Critical race methodology: Counter storytelling as an analytical framework for education research. Qualitative Inquiry 8(1): 23-44.

Visser, Gustav. 2007. Exploratory notes on the Geography of black gay leisure spaces in Bloemfontein, South Africa. B-WASP. http://bwasp.co.za/wp/?p=160 